\title{
Goldfuß was right: Soft part preservation in the Late Jurassic pterosaur Scaphognathus crassirostris revealed by reflectance transformation imaging and ultraviolet light and the auspicious beginnings of paleo-art
}

\author{
Kai R.K. Jäger, Helmut Tischlinger, Georg Oleschinski, and P. Martin Sander
}

\begin{abstract}
Reflectance Transformation Imaging (RTI) is a technique based on multiple digital photos with a fixed camera position and illumination from varying directions. These photos are processed to create an image file in which light source position and reflectance properties can be digitally modified. The method is frequently used in archaeology due to its abilities to visualize surface details. Here we apply RTI imaging to the holotype of the non-pterodactyloid pterosaur Scaphognathus crassirostris from the famous Solnhofen Lithographic Limestone of Late Jurassic age and compare the results with ultraviolet light (UV) imaging. The specimen is of particular historical interest since it was the first pterosaur for which a "fur-like" integument was described, by the German paleontologist and zoologist Georg August Goldfuß in 1831. His publication on this fossil includes detailed paleobiological inferences and culminates in the first published scientific life reconstruction of an extinct vertebrate in its environment. However, soft part preservation was not accepted by later scientists such as Herman von Meyer, and Goldfuß' work on soft part preservation, paleobiology and paleo-art was largely forgotten. With RTI and UV light, pycnofibres covering the neck and the body, as well as aktinofibrils and blood vessels on the wing membrane, were visualized on the Scaphognathus crassirostris specimen, largely confirming Goldfuß' observations. The application of RTI is technically easy and promising for paleontological studies, especially for flat fossils on slabs of sediment, where minor differences in relief might hold crucial information. To our knowledge, this is the first study to apply RTI to soft part preservation in vertebrate fossils.
\end{abstract}

Kai R.K. Jäger. Division of Paleontology, Steinmann Institute for Geology, Mineralogy, and Paleontology, University of Bonn, Nussallee 8, 53115 Bonn, Germany. jaegerk@uni-bonn.de

Helmut Tischlinger. Tannenweg 16, 85134 Stammham, Germany. htischlinger@online.de Georg Oleschinski. Division of Paleontology, Steinmann Institute for Geology, Mineralogy, and Paleontology, University of Bonn, Nussallee 8, 53115 Bonn, Germany. g.oleschinski@uni-bonn.de

Jäger, Kai R.K., Tischlinger, Helmut, Oleschinski, Georg, and Sander, P. Martin . 2018. Goldfuß was right: Soft part preservation in the Late Jurassic pterosaur Scaphognathus crassirostris revealed by reflectance transformation imaging and ultraviolet light and the auspicious beginnings of paleo-art. Palaeontologia Electronica 21.3.3T 1-20. https://doi.org/10.26879/713

palaeo-electronica.org/content/2018/2308-scaphognathus-in-rti-and-uv

Copyright: November 2018 Palaeontological Association.

This is an open access article distributed under the terms of Attribution-NonCommercial-ShareAlike 4.0 International (CC BY-NC-SA 4.0 ), which permits users to copy and redistribute the material in any medium or format, provided it is not used for commercial purposes and the original author and source are credited, with indications if any changes are made. creativecommons.org/licenses/by-nc-sa/4.0/ 
P. Martin Sander. Division of Paleontology, Steinmann Institute for Geology, Mineralogy, and Paleontology, University of Bonn, Nussallee 8, 53115 Bonn, Germany. martin.sander@uni-bonn.de

Keywords: Scaphognathus crassirostris; Goldfuß; Jurassic; soft part preservation; reflectance transformation imaging; UV light

Submission: 22 August 2016 Acceptance: 13 October 2018

\section{INTRODUCTION}

\section{Background}

The reconstruction of the biology of extinct animals, often called paleobiology, is generally seen as a field that developed in the late 20th century, with roots in the early part of the century. However, a relatively little known study (Goldfuß, 1831) of a pterosaur from the Upper Jurassic lithographic limestones of Bavaria, Germany, by the influential and well known German paleontologist and zoologist Georg August Goldfuß (1782-1848) indicates an early 19th century origin of scientific life reconstructions. The pterosaur specimen (specimen number SIPB Goldfuß 1304a, 1304b) (Figure 1), an articulated skeleton lacking the tail, distal hindlimbs and distal digits IV, is the holotype of the long-tailed pterosaur Scaphognathus crassirostris (Goldfuß, 1831). The specimen was acquired by Goldfuß in 1829 and is still preserved in the collections of the Goldfuß Museum (SIPB). The specimen was not only recognized as a new taxon by Golduß (1831) but also to show remarkable soft part preservation (Figure 2), consisting of an extensive cover of pycnofibers, aktinofibrils in the actinopatagium and blood vessel impressions on the wing membrane (see section Results below). These preserved soft parts inspired him to produce the first life reconstruction of an extinct vertebrate in its environment (Figure 3) to be published in a scientific journal, the Nova Acta Leopoldina (Goldfuß, 1831). This fact is generally known to the scientific community (Rudwick, 1992; Martill, 2014), but Goldfuß also offered an extensive and strikingly modern discussion of the paleobiology of pterosaurs that is largely forgotten (despite the translations text box in Rudwick, who chose not to translate the crucial parts on soft tissues). Outspoken scepticism by the leading German reptile paleontologist of the 19th century, Hermann von Meyer (1846, 1859), seemingly eclipsed Goldfuß' revolutionary research, and only new pterosaur finds in last decades of the 20th century confirmed his observations and interpretations. The soft part preservation of the Scaphognathus crassirostris holotype specimen itself, although briefly men- tioned by Wellnhofer (1975), had not received any study until the new millennium. It is the purpose of the current contribution to rectify this, employing two modern techniques to visualize the soft parts, filtered UV imaging and reflectance transformation imaging (RTI). The latter has scarcely been applied to fossils before (Hammer et al., 2002; Hammer and Spocova, 2013) and never to pterosaurs or any other Solnhofen fossils. We do not aim at improving knowledge about pterosaur soft part anatomy and preservation but note that our paper combines application of a new method (RTI) with a historical perspective. A detailed restudy of the Goldfuß Scaphognathus crassirostris is in progress, however.

In the literature on vertebrate fossils from lithographic limestones, the term "soft tissue preservation" has been used for two different phenomena, the impression left by soft tissues in the finegrained limestone matrix and for actual altered non-mineralized tissues, preserving some of their substance. In this study, the term "soft tissue preservation" refers to both kinds, but different imaging techniques are suitable for impressions of soft tissues vs. substance preservation of soft tissues.

On a terminological note, we use the spelling "aktinofibrils" (e.g., Wellnhofer, 1991) in this contribution as opposed to "actinofibrils" because the former spelling was used earlier than the latter. The term is based on the Greek word aktinos; "ray, beam", as in Actinopterygii, not on the protein "actin". In the German literature, the Greek word is directly transliterated with a "kappa" as "aktinos", but in the English literature the transliteration via Latin (which does not have a " $k$ ") is more commonly seen, hence "actinos" and "actinofibrils". This transliteration of a Greek "kappa" via Latin as a "c" is also seen in the companion term "pycnofibers" coined by Kellner et al. (2010) for hair-like fibers in pterosaurs.

\section{History of Research}

1830: Printing of Buckland's Duria Antiquior. This famous and often reproduced image of the Early Jurassic marine environment of southern England known as Duria Antiquior (a more ancient 


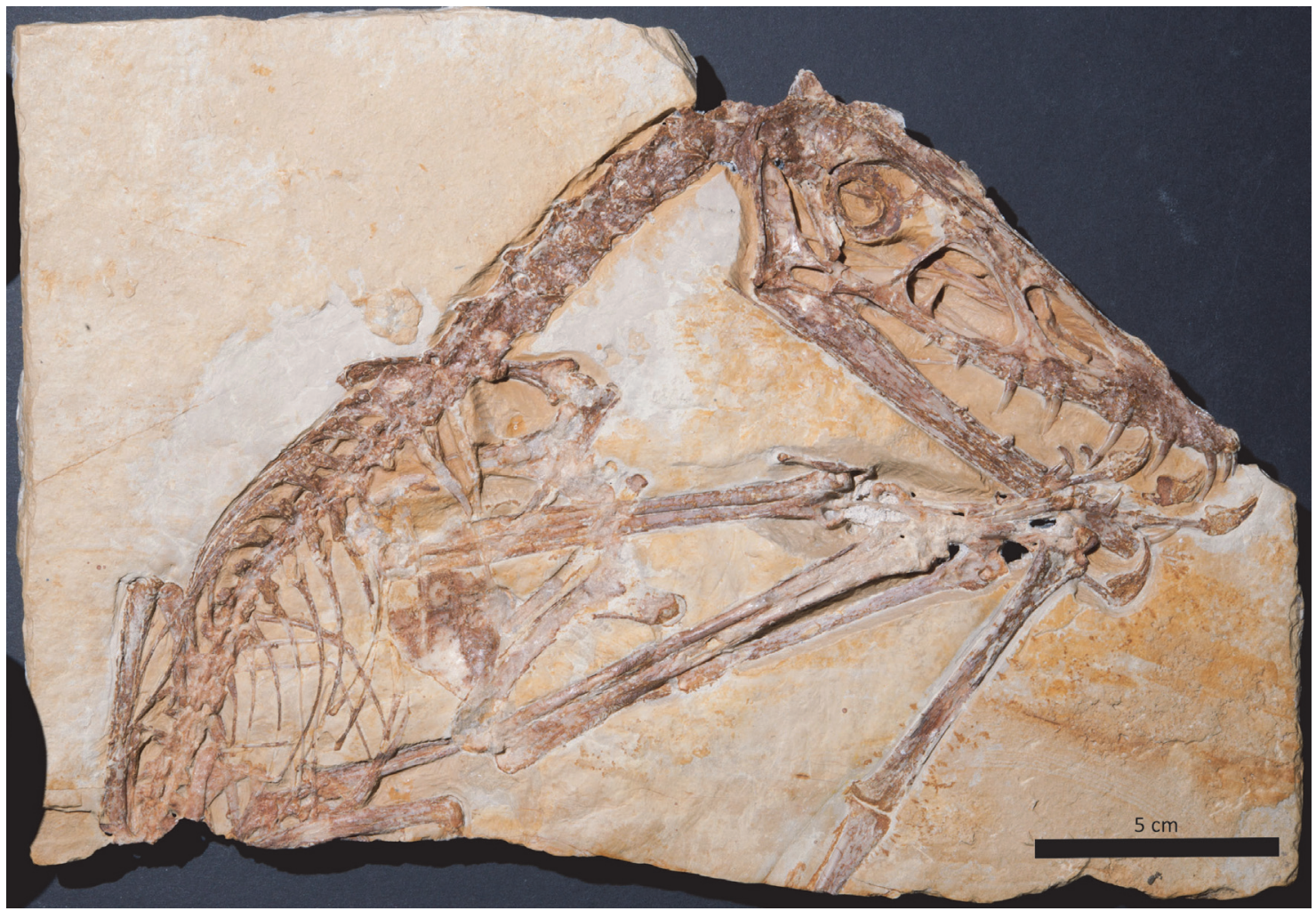

FIGURE 1. Photograph of the main slab of the holotype specimen of the non-pterodactyloid pterosaur Scaphognathus crassirostris (Goldfuß, 1831) catalogued as SIPB Goldfuß 1304a from the Late Jurassic Solnhofen Lithographic Limestone of Bavaria. The skeleton is seen in right lateral view with the skull, neck, trunk, and much of the limbs preserved. The skull was prepared from both sides by Georg August Goldfuß himself (Goldfuß, 1831). Preserved soft parts are not immediately obvious in this photograph.

Dorset) contains a life reconstruction of pterosaurs. The image seemingly came to the attention of Goldfuß (Rudwick, 1992) when he already was in the possession of the Scaphognathus crassirostris holotype specimen which he had acquired in 1829.

Duria Antiquior was produced in support of the poor Lyme Regis collector Mary Anning by the leading paleontologist William Buckland (Rudwick, 1992) who had studied the fossils from Lyme Regis. It shows pterosaurs, which had been found in the Lower Jurassic strata at Lyme Regis (Dorset, England), flying over a Jurassic sea teeming with ichthyosaurs and plesiosaurs. The scene was executed by the geologist Henry De al Beche, who was not artistically trained, more in the style of a cartoon than a realistic depiction of ancient life (Rudwick, 1992). Important features with regard to pterosaurs are that they were shown as active flyers and as naked-skinned reptiles. Numerous copies of Duria Antiquior were printed to be sold in support of Mary Anning, but the prints were not accompanied by a written explanation, let alone a scientific text providing justification for the paleobi- ological hypotheses visualized by De la Beche and Buckland. A slightly earlier life reconstruction of a flying pterosaur was produced as a painting by a Reverend Howman, but reconstruction was neither scientific nor was it published (Martill, 2014).

Goldfuß (1831): Life reconstruction of Scaphognathus crassirostris. The credit for having published the first scientific life reconstruction of an extinct vertebrate in its environment must go to Goldfuß (1831). He commissioned his illustrator, the Bonn artist and university drawing teacher Christian Hohe (Cremer, 2001), to produce this image (Figure 3 ) as part of a larger lithographic plate with a large skeletal reconstruction and an illustration of the skull (Goldfuß, 1831, plate 9) to accompany the scientific description. In addition to the life reconstruction image, tucked away in the lower right corner of the plate (Figure 3 ), the text contains an extensive scientific justification for the life reconstruction as well as the skeleton reconstruction. The German text is not widely available and little read, therefore a translation by PMS of selected parts has been added to the Supplemen- 


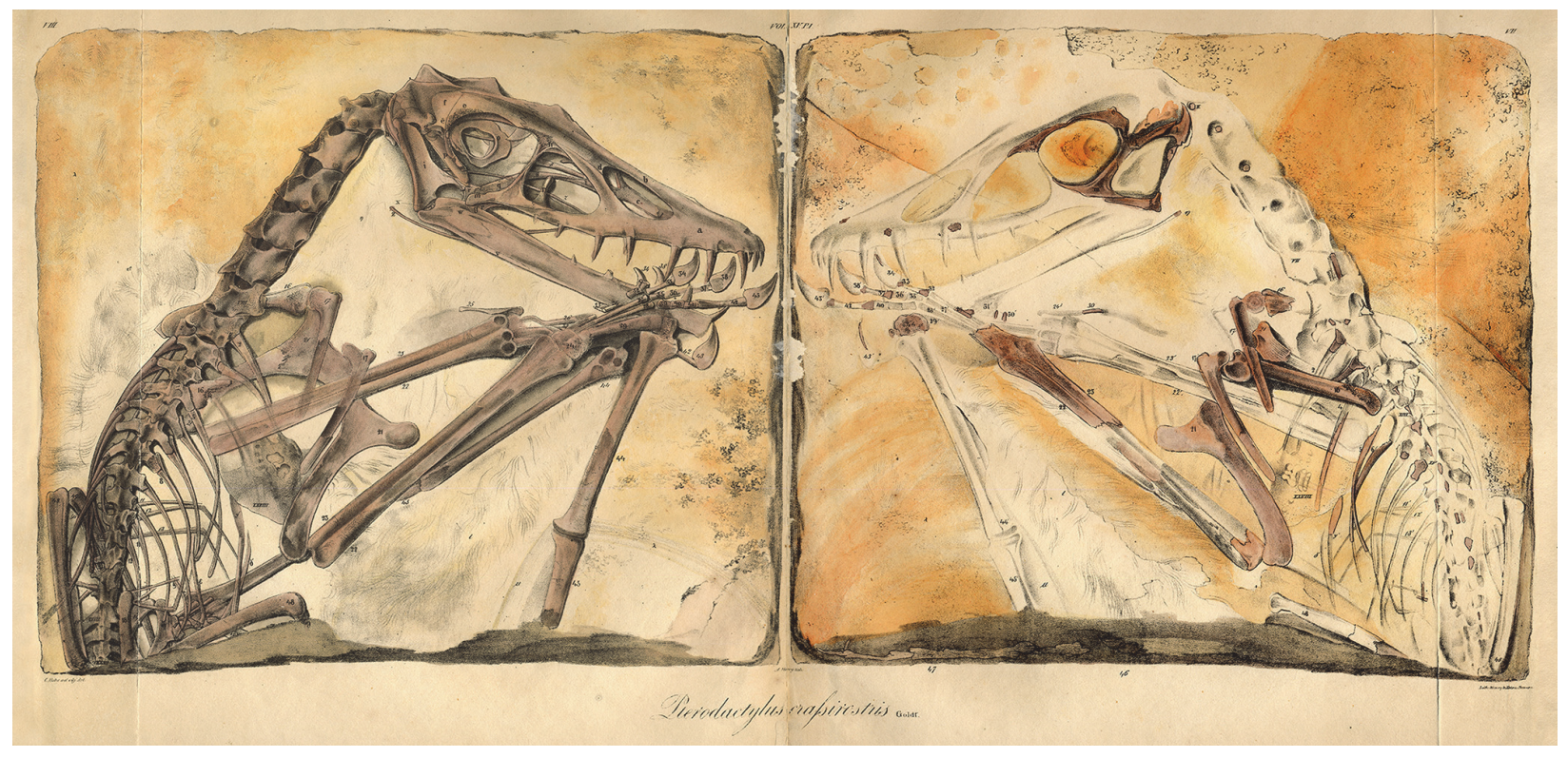

FIGURE 2. Hand-colored lithographic plates drawn by Nicolaus Christian Hohe from Goldfuß (1831) showing main slab (SIPB Goldfuß 1304a: Goldfuß, 1831, plate 8) and counterslab (SIPB Goldfuß 1304b: Goldfuß, 1831, plate 7) of the holotype specimen of Scaphognathus crassirostris. Note the high accuracy of the images but the artistic license. This consists of depicting the slab as a rectangular plate, although the actual specimen (see Figure 1) is missing the upper right corner because Goldfuß prepared the skull from both sides. In the lithographs, Goldfuß had the soft part preservation depicted and labelled (see also Figure 10).

tary Materials (Supplementary Material 1). What lead Goldfuß to produce this life reconstruction? This has not been sufficiently researched from archival material, but it is likely that his ideas developed in parallel to those of the English paleontologists, and both were presumably based on earlier ideas by Cuvier. It certainly would not do Goldfuß justice to suggest (as Rudwick, 1992, did) that he copied the idea from Buckland's and De la Beche's Duria Antiquior. Instead, it seemingly was the strong influence of the romantic movement and natural philosophy in Goldfuß' background and earlier work that enabled him to envisage and illustrate past worlds. Before accepting the professorship in Bonn in 1818, Goldfuß had worked in Franconia (Langer, 1969; Becker, 1999; Thomann, 2016), the cradle of German romanticism. Historical research and an analysis of his early publications indicates that Goldfuß was deeply influenced by the romantic movement and that of natural philosophy (Langer, 1969, Thomann, 2016). A material expression of this survives to this day, the neogothic Rosenburg Castle in Bonn-Kessenich, which was built by Goldfuß also in 1831 and, more importantly, given an imaginary medieval history (Langer, 2003).

Contemporary early 19th century reception. Although there was competition between the
English paleontologists and Goldfuß (Rudwick, 1992), they quickly copied Goldfuß' illustration and accepted his paleobiological interpretation of hair and an active lifestyle (see below). This is evident from Buckland's 1836 book for laymen "Geology and Mineralogy" (Buckland, 1836), one of the Bridgewater Treatise volumes. In it, there is an obvious copy of the Goldfuß/Hohe illustration (Rudwick, 1992, figures 21 and 29; Martill, 2014, figure 13), without mention of Goldfuß, however (Martill, 2014). Buckland's pterosaurs are now clearly hairy (after being naked in Duria Antiquior), a fact that is only hinted at in the grainy lithograph by Hohe (Goldfuß, 1831, plate 9). The interpretation of pterosaurs as being hairy seemed to have remained unchallenged for the next decade, and in a way was epitomized by the English zoologist Edward Newman who in 1843 illustrated a living hairy pterosaur, seemingly modeled on Scaphognathus crassirostris because of the large skull. Newman (1843), however, viewed pterosaurs as mammals, more precisely as flying bat-like marsupials. Newman may have been inspired by a misreading of Goldfuß (1831, p. 13) who drew comparisons with marsupials and monotremes but recognized that pterosaurs unquestionably were reptiles. 


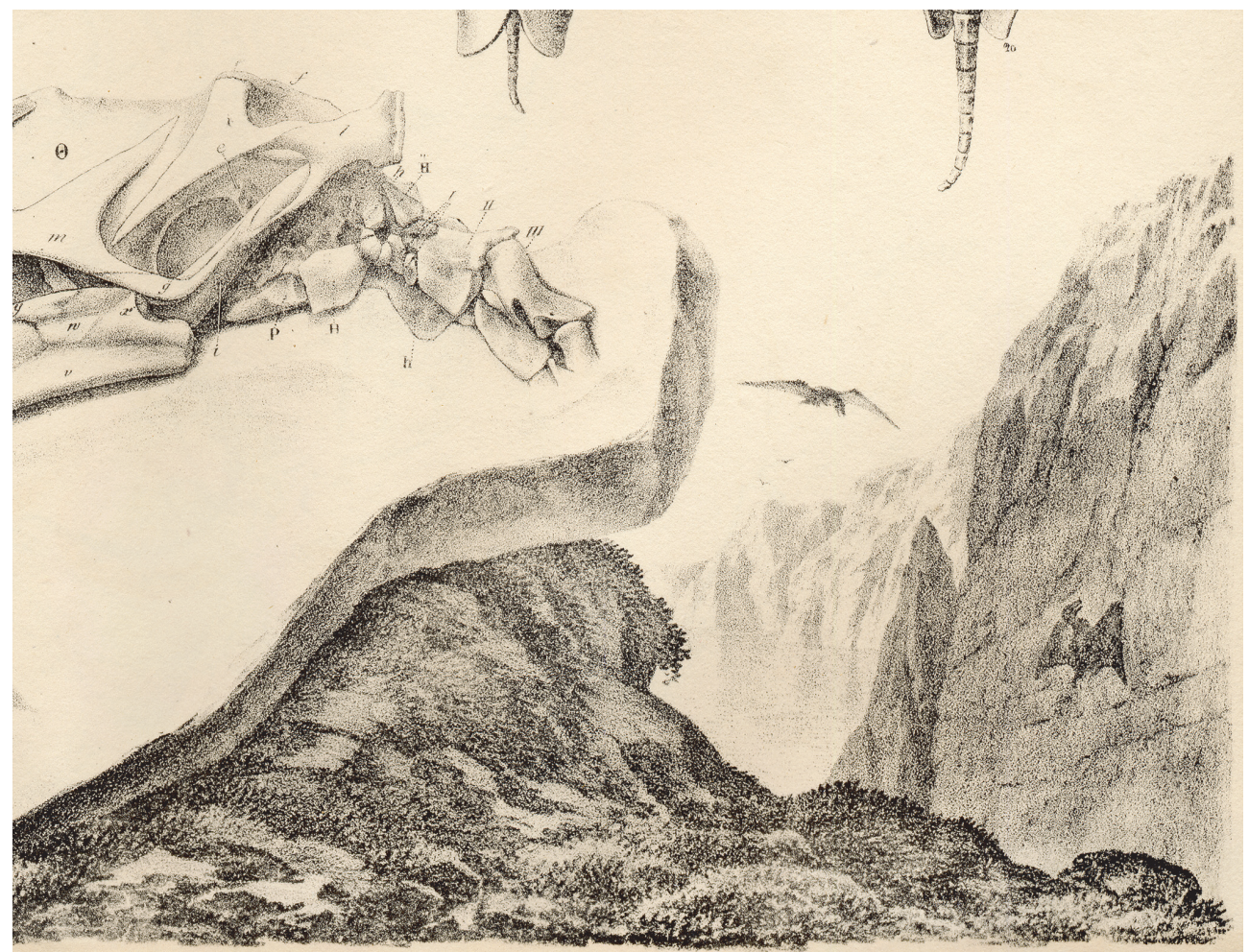

FIGURE 3. Scaphognathus crassirostris life reconstruction. This illustration was published by Goldfuß (1831) as a vignette in the lower right corner of a larger plate (tab. IX) that contains drawings of the skeletal reconstructions of Scaphognathus crassirostris. This vignette is the first life reconstruction of an extinct vertebrate in its environment in a scientific publication (Rudwick, 1992).

Meyer (1846, 1859): Rejection of soft part preservation. By the middle of the 19th century, when vertebrate paleontology firmly became established as a separate discipline and natural philosophy had become discredited in scientific circles, one of the founding fathers of vertebrate paleontology in Germany, Herman von Meyer (1801-1869), virtually eclipsed Goldfuß' study of 1831. In his detailed 1859 monograph (Meyer, 1859), based on an earlier publication of 1846 (Meyer, 1846), Meyer rejected any presence of preserved soft parts (see below) on the specimen. The 1846 publication is telling in that Meyer only studied the specimen firsthand 10 years later, in 1856. Meyer ascribed Goldfuß' observation to an overly vivid imagination, echoing the contemporary rejection of romanticism and natural philosophy, and suggested that the preserved soft parts had an inorganic origin as metal oxide precipitates. Owing to Meyer's authority and the general lack of interest in paleobiological research during the latter half of the 19th century, meant that Goldfuß' work was forgotten. Renewed interest in pterosaur integuments and biology only arose in the last third of the 20th century (Wellnhofer, 1970, 1975, 1991; Unwin and
Bakhurina, 1994). Specifically, new fossils from other localities than Solnhofen revived the idea of "hair-like structures" in pterosaurs (Sharov, 1971; Padian and Rayner, 1993; Unwin and Bakhurina, 1994).

Wellnhofer $(1975,1991)$ : The beginning of modern research. As an introduction to his extensive discussion of the integument preserved in Rhamphorhynchus, Wellnhofer (1975) notes that "Goldfuß thought he had detected hair in the Scaphognathus crassirostris holotype" (Goldfuß, 1831; Supplementary Material 1). However, Wellnhofer (1975) does not mention Goldfuß' work any further nor does he use it in his own interpretations. Similarly, in his influential book on pterosaurs (Wellnhofer, 1991), Wellnhofer gives the impression of not believing Goldfuß' discovery of soft parts in the Bonn Scaphognathus crassirostris since he writes "August Goldfuss ... thought he found prints of hair in a Solnhofen pterosaur" (Wellnhofer, 1991, p. 163, see also p. 27 and p.168). Finally, Wellnhofer (1991, figure on p. 146) reproduced Buckland's rendition of the life reconstruction of Goldfuß' Scaphognathus crassirostris instead of the artistically much better original 
although he must have been aware of the artistic legacy one owes to the other.

Langer (1990) and Rudwick (1992): Reception by historians of science. Goldfuß' contribution as one of the founding fathers of paleobiology was beginning to be recognized only in the last decade of the 20th century. Rudwick (1992) compiled a history of "Scenes from Deep Time" and credited Goldfuß with producing the first scientific life reconstruction in paleontology ever published. This recognition followed on the heels of a small article by W. Langer in a German fossil collector's magazine (Langer, 1990) where he makes the first mention of this fact, and also provided the information to Rudwick (Langer, personal commun., 2015). Neither of them, however, rehabilitated Goldfuß' paleobiological hypotheses expressed in his publication.

Tischlinger $(2003,2006)$ : Soft part preservation detected by UV light. The claims of Goldfuß about soft tissue, in particular "hair" preservation in the Scaphognathus crassirostris holotype, remained disputed until Tischlinger $(2003,2006)$ used UV light to reexamine the specimen. He was able to confirm preserved soft tissue, such as aktinofibrils, at most of the positions identified by Goldfuß 172 years earlier. Tischlinger thus restored the position of Goldfuß as "the father of paleobiological pterosaur research" (Tischlinger, 2003). Tischlinger specifically noted the fibers on the back of the animal and the wing membrane, which were mentioned by Goldfuß and which are already visible with oblique incident light, standing out clearly in filtered UV light. Tischlinger and Frey (2015) also briefly note "the hair like structures" mentioned by Goldfuß and filtered UV light imaging, without going into detail, however. In addition to the reinvestigation of Scaphognathus crassirostris, several other studies on soft tissue preservation of pterosaurs from the Solnhofen limestone have been published by Tischlinger (Frey and Tischlinger, 2000; Tischlinger, 2002; Tischlinger and Frey, 2002; Tischlinger, 2005). In these studies as well, soft tissue structures were visualized with UV light already during preparation.

\section{Soft Tissue Preservation in Pterosaurs: State of the Art}

In the late nineteenth and early twentieth century, many publications had addressed soft tissue preservation in Solnhofen pterosaurs, specifically on the wing membranes or patagia (Winkler, 1874; Marsh, 1882; Zittel, 1882; Wanderer, 1908) and hair-like structures and membranes between the toes (Wiman, 1925; Broili, 1927, 1938; Döderlein,
1929). A detailed summary of these studies is provided by Wellnhofer (1975, 1991). More recently, soft tissue preservation of pterosaurs has been reported from several different conservation lagerstaetten such as in the Triassic of Italy, Lower and Upper Jurassic of Germany, Upper Jurassic and Lower Cretaceous of China, and Lower Cretaceous of Brazil (e.g., Unwin and Bakhurina, 1994; Dalla Vecchia, 1994; Kellner, 1996; Frey et al., 2003; Kellner et al., 2010). An amazing array of preserved soft tissues have been reported, including remains of the respiratory system, gut, brain, musculature, integument and patagia (Witton, 2013). Tischlinger and Frey (2002) and Frey et al. (2003) were the first to convincingly describe the histological complexity of the brachiopatagium and its composition of at least three separate layers of fibers, fascia and blood vessels.

Kellner et al. (2010) distinguished between three different types of fibers present on the patagium and in the integument of Jeholopterus. The first type are aktinofibrils. They are densely packed, with an individual thickness of $\sim 0.1 \mathrm{~mm}$. They are only present on the distal part of the plagiopatagium/brachiopatagium (= aktinopatagium of Schaller, 1985) (Schaller, 1985; Unwin and Bakhurina, 1994; Bennett, 2000). Bennett (2000) noted that these fibers most likely consisted of keratin, dense collagen or cartilage, although the last is a skeletal tissue, and its presence in a wing membrane is highly unlikely. The term aktinofibrils only refers to the elongated, stiff fibers on the distal part of the wing membrane (Witton, 2013). The second type of fibers in Jeholopterus are thicker and scarcer than aktinofibrils (Kellner et al., 2010). They either represent more robust aktinofibrils or blood vessels (see also Frey et al., 2003). The third type of fibers seen in in Jeholopterus are described by various modern authors as "hair" or "integumental covering" (Wang et al., 2002). They form unorganized and thicker structures than aktinofibrils and were named "pycnofibers" by Kellner et al. (2010). Pycnofibers probably covered the whole body and parts of the head of pterosaurs but were absent on the patagium, with few exceptions (Witton, 2013). Although their chemical composition is unknown, it is reasonable to assume that pycnofibers were keratinous (Kellner et al., 2010; Witton, 2013).

\section{MATERIALS}

The specimen, on which this study is based, is the holotype specimen of the long-tailed pterosaur taxon Scaphognathus crassirostris (Figure 1) 
(Goldfuß, 1831). It is preserved in the collections of the Golduß Museum, Division of Paleontology, Steinmann Institute for Geology, Mineralogy, and Paleontology of the University of Bonn, Bonn, Germany. As extensively described by Goldfuß (1831), the specimen was split into a slab and a counterslab during discovery and further prepared by him. In particular, he prepared the skull, most of which remained on the slab, from the back side as well, which is not evident from the lithograph depicting slab and counterslab (Figure 2) but from plate 9 in Goldfuß (1831). Thus the slab is missing the upper right corner, and the lithograph (Figure 2) may either represent an idealized view or an earlier stage of preparation. Today, slab and counterslab are preserved in their period protective wood-andglass boxes, and inventoried as "Goldfuß 1304a and b".

As noted by earlier workers (Tischlinger, 2003), the preparation performed by Goldfuß himself is of a quality that would not be surpassed significantly today. This preparation work represents a remarkable feat, given the lack of binocular microscopes. Goldfuß mentions that he used a needle (Grabstichel), and we suspect that he must have used a watchmaker's lens for magnification. He notes the use of a hand lens to examine the preserved soft parts.

\section{METHODS}

\section{Polynomial Texture Mapping and Reflectance Transformation Imaging}

Polynomial texture mapping (PTM) is an image data format first described by Malzbender et al. $(2000,2001)$. In a .ptm file, each pixel contains information about its luminescence properties in addition to the regular color information red, green and blue (RGB). This information is present as coefficients about the light reflection, gathered from different pictures with varying incoming light direction. Additionally to color and reflectance properties, information about the surface is stored, based on the estimation of normal vectors for each pixel (Earl et al., 2010; Hammer and Scopova, 2013). As a result, a PTM file functions as an image with a virtual movable light source (Hammer et al., 2002).

While the specific approach of Malzbender et al. (2001) is called PTM, the overall method is named reflectance transformation imaging (RTI) (Earl et al., 2010). The latter includes varying numbers of coefficients, underlying algorithms and different polynomials used to interpolate between the taken pictures. For this study, we processed the imaged pictures into two different data formats, the original .ptm file and .rti files. The second format was developed by the nonprofit organization Cultural Heritage Imaging, primarily for archaeological and historical artifact documentation and research.

Several archaeological studies successfully applied RTI/PTM over the last years (e.g., Earl et al., 2011; Piquette, 2011; Kotoula, 2012; Duffy et al., 2013). Compared to archaeological studies, RTI/PTM imaging is rather scarce in paleontology, and only .ptm files have been used so far (Hammer et al., 2002; Hammer and Scopova, 2013) but not .rti files.

Photography. There are two different photographic techniques to capture the images used in RTI (Piquette, 2011), the stationary dome technique and the mobile highlight technique. The latter method was applied in this study. In terms of equipment, capture only requires a tripod, a camera, a black sphere and a movable flash (Piquette, 2011; Duffy et al., 2013). The imaging session takes about 10-15 minutes per object. While the technique offers portability and low cost, it is less time efficient than the dome technique described below.

In the mobile highlight technique, image capture of the object, in our case the Scaphognathus crassirostris specimen, works as follows: The fossil is placed on the studio table or any other flat surface. The camera is mounted above the specimen (or in case of a vertically positioned fossil, in front of it). It is crucial that the camera and object are stationary, since even slight displacement requires a restart of the capturing process. A reflective black sphere is placed next to the fossil and functions as a reference point for capturing the incoming light direction. While we were able to produce good results with other colored reflective spheres, even with a white one, we suggest a black sphere to avoid problems during the later processing. For this study, we used black snooker balls.

Next, multiple pictures are taken (30-50) with varying flash positions. During the capture sequence, the pictures are saved as .raw and later changed to .jpg for processing. The flash is positioned at a distance of approximately three times the diameter of the object, facing it directly. While the manual of the RTI developers suggests an exact flash distance for every photo taken (Bogart, 2013a), we could not find any differences in the results whether the distance between flash and object was determined by measuring for each photo or by just estimating the distance. However, 

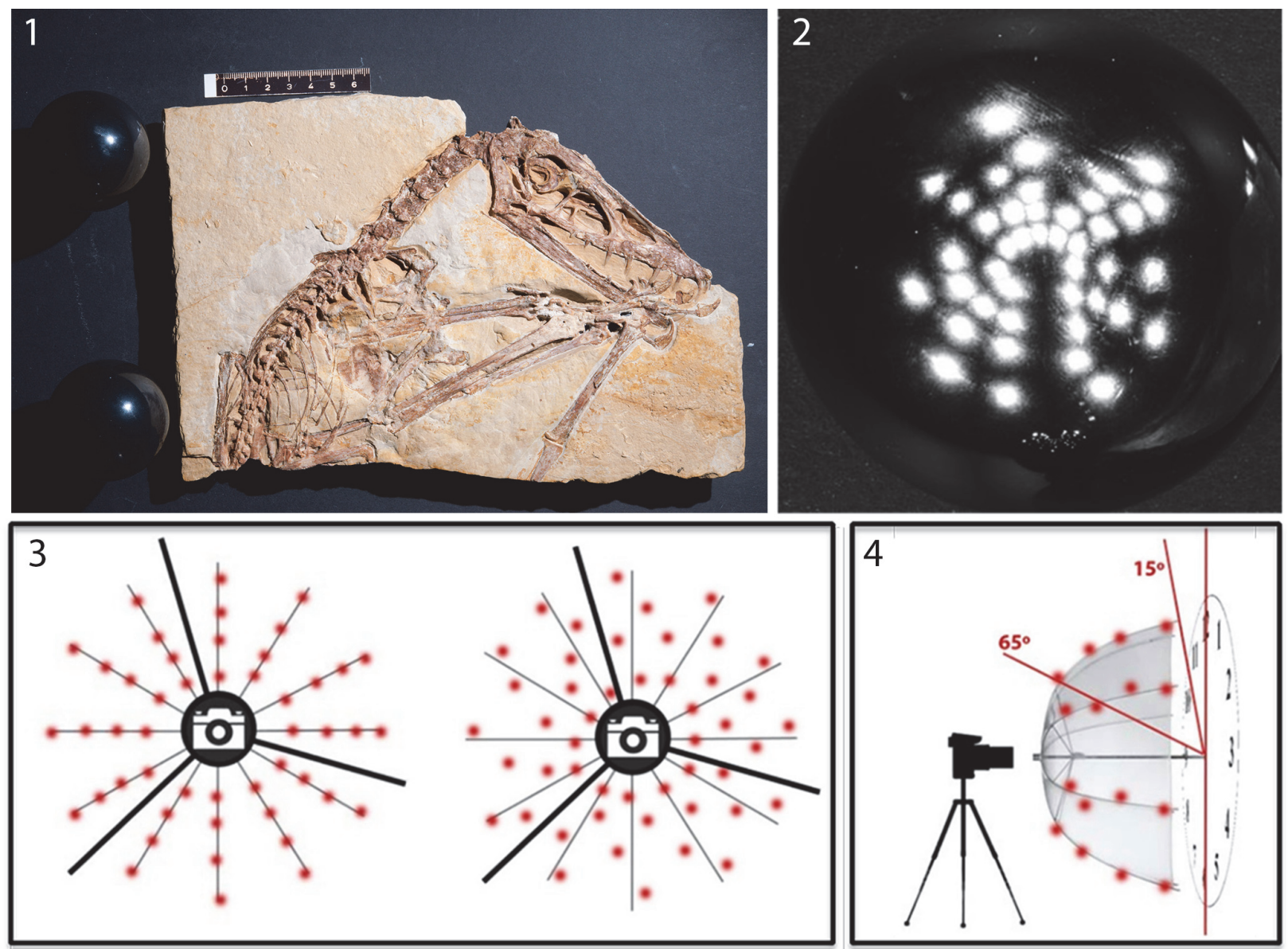

FIGURE 4. Photography setup for the mobile highlight technique of image capture for RTI/PTM imaging. 1, A single source photograph from the capturing process. The light source (flash) is positioned on the upper right side as seen on the reflectance of the black reference spheres. 2, A composite image of all flash positions is generated by the RTIBuilder software to check if spaces were missed during the capturing process. The elongate gap at the bottom is caused by one of the legs of the tripod. 3, The setup in top view. The camera is positioned above or in front of the target. The flash is moved along a contour of a virtual hemisphere at a distance of approximately three times the diameter of the object. The red dots symbolize the flash positions for the captured images. Left: Good distribution of flash positions that leaves no gaps and covers the whole object, recommended for inexperienced photographers. Right: Ideal distribution with equal distance between flash positions. 4, The setup in side view with the camera, the object, the virtual hemisphere, and flash positions. The flash positions should be at angles from at least $65^{\circ}$ to $15^{\circ}$ to the object. 3 and $\mathbf{4}$ are modified from Bogart (2013a).

the amount of time required for each photo is much less without distance measurements.

The flash is placed around the object in an attempt to cover an imaginary hemisphere over the object, using angles between almost $70^{\circ}$ down to $15^{\circ}$ above the surface. While this could be done with systematic placement of flash positions along virtual arcs with the same distance from the highest angle to the lowest angle, it is even better to shift each flash position slightly to the left or right from the arc to reduce the distance between each spot (Bogart, 2013a) (Figure 4).

For the dome technique, a hemisphereshaped frame with several white LED lights attached is required (Hammer et al., 2002), covering the hemisphere in a similar way that moving a single flash would. The camera is fixed to the top of the sphere. Additionally, a computer program is required that triggers the different LED lights one after another, while the camera takes pictures automatically. The technique requires a certain amount of technical skill for building the setup and programming knowledge for operating it. As far as we are aware, there is no company that sells RTI domes nor the necessary software. Compared to the mobile highlight technique, the downside of dome technique is a greater installation effort, higher material costs, less mobility, and a limitation 

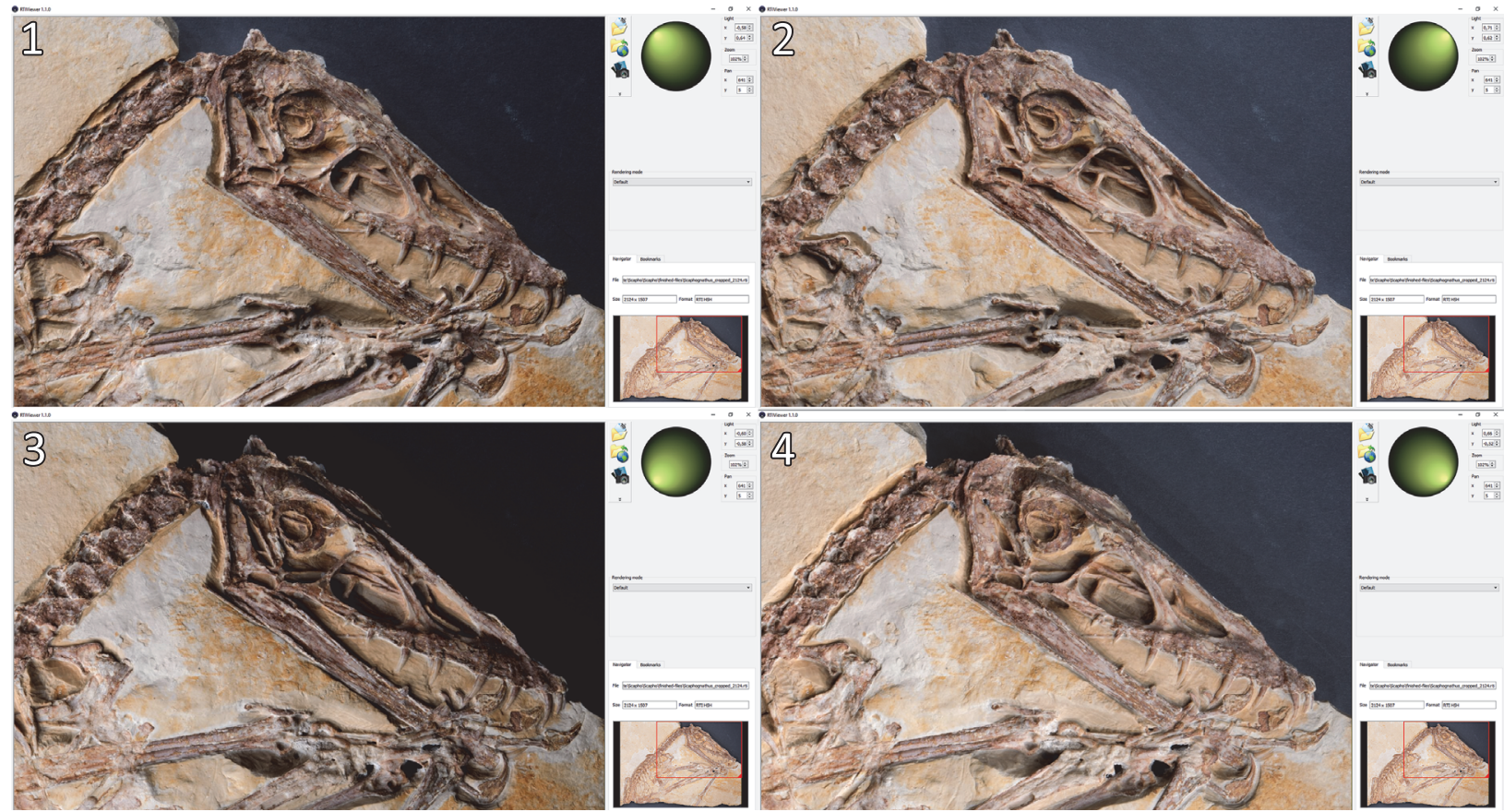

FIGURE 5. 1-4, Series of RTIViewer snapshots of the .rti file of the main slab (SIPB Goldfuß 1304a) of the holotype specimen of Scaphognathus crassirostris with low-angle light from different directions in default rendering mode. Light positions (green sphere) and a navigation overview is visible on the right side of each image. The direction of the light source can be manipulated by clicking on the green sphere or by assigning specific coordinates to the light source position.

of object size. The upside is that it offers faster image capture, making it useful for large amounts of similar-sized objects (Dellepiane et al., 2006).

File building. After the pictures are taken with either technique, they are processed with the freeware "RTIBuilder" (Barbosa et al., 2007a, 2007b). The processing of the image files takes approximately 10 minutes and results in a .rit or .ptm file, depending on the type of algorithm applied. As noted, the processing modes to create a rti or a .ptm file differ in the polynomials, which are used to interpolate between the pictures taken. For this study, we used rti files, which produced better results with the highlight technique, even though they lack some rendering modes available with .ptm files. Due to relatively low computer hardware requirements for processing, the final resolution of the files is only limited by camera resolution. After processing, both file types can be displayed with the freeware "RTIViewer" (Palma et al., 2010; Corsini et al., 2012). This simple tool offers the virtual manipulation of direction of the light source as well as different rendering options. The user interface of the software is simply designed with the image of the photographed object on the left and the setting on the right. A virtual sphere enables the user to freely manipulate the position of the vir- tual light source with the mouse (Figure 5). Multiple rendering modes allow manipulation of the reflectance properties (Figure 6). The specular enhancement mode is used reduce the RGB information and to manipulate the specularity of the object as well as the highlight size (matte vs. shiny reflection) (Figures 6.1-3, 7, 8). The normals visualization mode presents a false color image where each pixel has a color determined by its orientation relative to the horizontal (Figure 6.4). Both modes are available in .rti and .ptm files, while the following modes are limited to .ptm only.

Diffuse gain enhances the height of steep slopes causing cavities to appear deeper and elevations higher. Color might be affect as a side effect. Four different types of unsharpening masks are available to create a sharpening effect for different parameters such as color (image unsharp masking), surface and color contrast (normals unsharp masking), pure surface contrast (luminance unsharp masking) and reflectivity (coefficient unsharp masking). The static multi light mode creates an image with multiple virtual light sources with high contrast. In our study, the visibility of details was enhanced in the .ptm files. However, in some cases the picture appeared "inverted" as an optical illusion, similar to the effect of an illumina- 

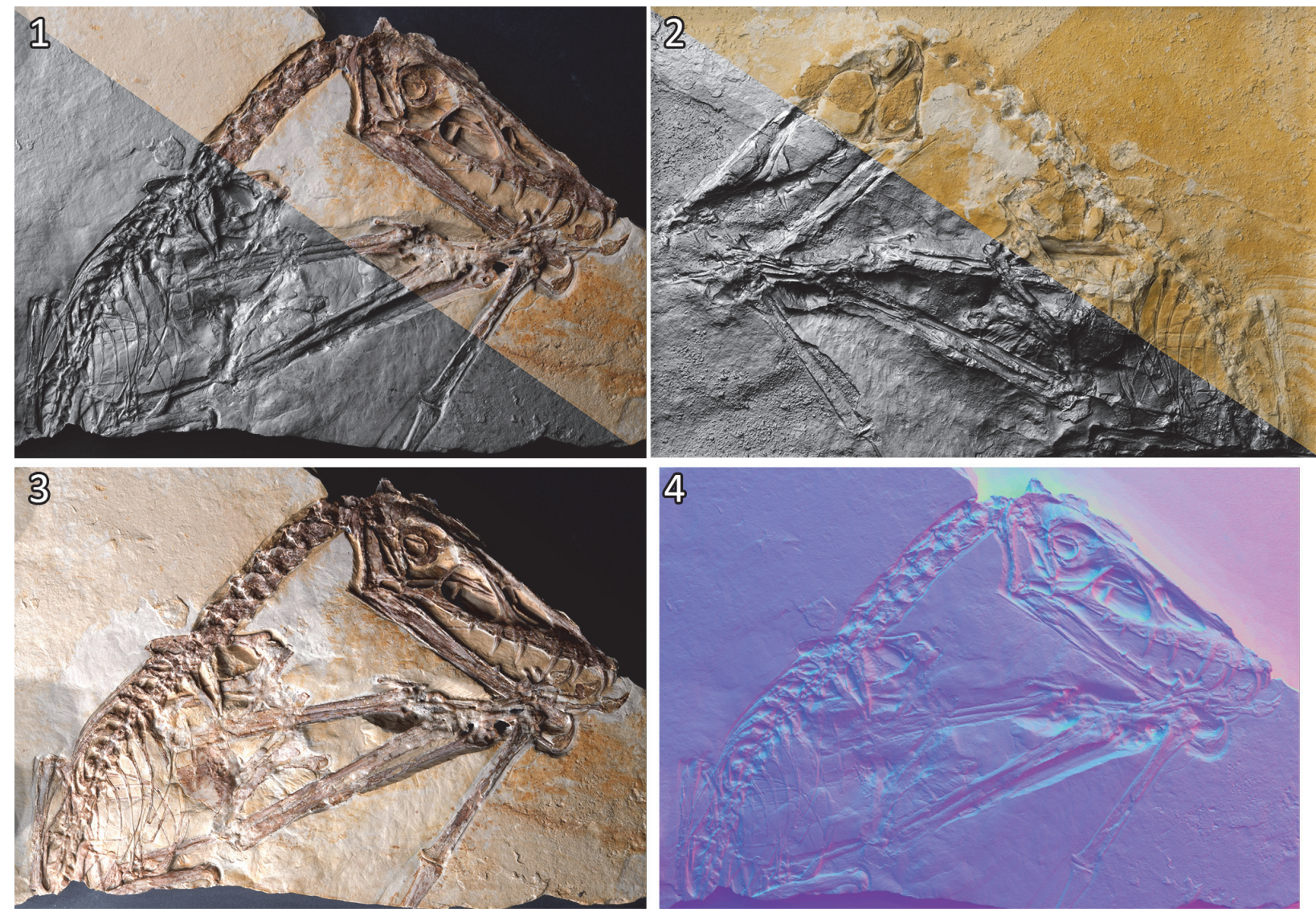

FIGURE 6. The main slab (SIPB Goldfuß 1304a) of the holotype specimen of Scaphognathus crassirostris with snapshots of different rendering modes of the .rti file. Light is from the upper left. 1, Image of main slab showing default setting (upper right) and specular enhancement with erased color information, medium specularity and highlight size (lower left). 2, Image of counter slab (SIPB Goldfuß 1304b) showing default setting (upper right) and specular enhancement with erased color information, medium specularity and highlight size (lower left). 3, Main slab viewed with color information, enhanced specularity and low highlight size. 4, Main slab viewed in normals visualization mode.

tion from the lower left instead of the traditional upper right. Dynamic multi light enables the user to move the primary light source, which is not possible in static multi light and to change properties of the additional light sources. Palma et al. (2010) provide detailed information about the different rendering modes available in RTIViewer with .ptm files. A snapshot function is present for both type of files, as well as a zoom function, which enables digital magnification of up to 200 percent (Figure 8) (Bogart, 2013a, 2013b).

The .rti files computed for the main and counter slab of the Scaphognathus crassirostris specimen were $37 \mathrm{MB}$ and $27 \mathrm{MB}$ in size, respectively (Supplementary Material 2). To make the soft tissue visible, we used low-angle lighting from different directions and the specular enhancement rendering mode. By setting the diffuse color slider to 0 , we removed the color information from the file, which resulted in a better visibility of the relief. We used the sliders "Specularity" and "Highlight size" together with the light position in many different positions to determine the best setting for each soft tissue structure on the slabs. Note that in RTIViewer, the position of the light source is displayed as $x$ and $y$ values in a coordinate system, with the center of the light hemisphere having $x$ and $y$ values of 0 .

\section{UV Imaging of Specimen}

The remarkable results of UV imaging are based on the preservation of the substance of soft tissue as the phosphate mineral apatite. The phosphate mineral does not appear different from the surrounding rock matrix to the naked eye, but it fluoresces in varying wavelengths of UV light (Tischlinger and Frey, 2002; Frey et al., 2003). Since each fossil fluoresces slightly differently, a variety 

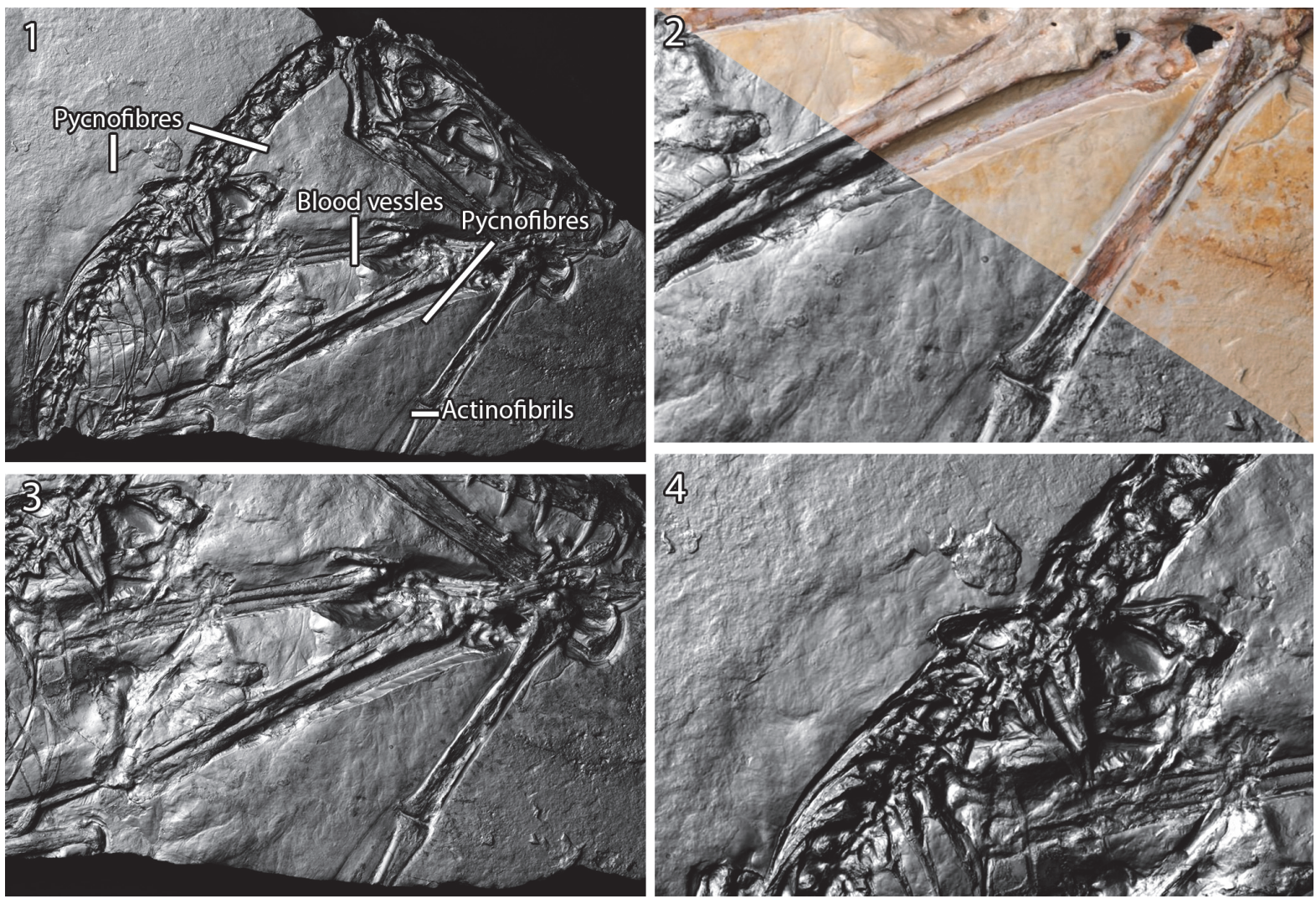

FIGURE 7. Close-ups of RTIViewer snapshots of the .rti file of the main slab (SIPB Goldfuß 1304 a) of the holotype specimen of Scaphognathus crassirostris showing soft parts with different settings and light positions. Compare to Figure 9. 1, Soft tissue with specular enhancement rendering and low-angle light. 2, Comparison of the close-up of the right arm divided between default view and specular enhancement. Note that the pycnofibers and the region of the wing membrane with the aktinofibrils is much better visible with specular enhancement 3, Specular enhancement of the region of the wing skeleton. Impressions of blood vessels and pycnofibers are clearly visible, while the aktinofibrils next to the joint of the first and second phalanx are hardly visible. 4, Dorsal region with specular enhancement. Pycnofibers are much better visible compared to the UV light image (Figure 9.2).

of filters and high performance UV-A lamps is required for this imaging method (Frey and Tischlinger, 2012; Tischlinger and Arratia, 2013; Tischlinger, 2015). For our investigations, we used different UV-A lamps with a wavelength of 365-366 $\mathrm{nm}$. Powerful modern UV-A lamps emit a UV intensity between 4,000 and more than 90,000 microwatts per $\mathrm{cm}^{2}$, depending on the distance and the number of lamps.

The application of different filters allowed a selective visualization of fine structures. Color compensation filters (yellow, cyan and magenta of different types and densities) were custom-made from special colored glass or gel. They were adjusted in front of the camera lens or the microscope front lens, both for observation and for taking pictures through the microscope. The optimum number and specification of the compensation filters was tested in a series of experiments. Note that the filters in front of the lens did not alter the wavelength of the UV source, but that their proper application generates maximum contrast between soft parts and non-fluorescent or poorly luminescent matrix. The furthermost filter is a UV Filter, blocking UV light up to 390 nanometers.

As safety precaution, it is imperative to wear gloves, long-sleeved clothing and UV-blocking eye glasses. In order to enhance picture quality by reducing reflections of cloths, it is advisable to dress in black or very dark gray while working, since many light-colored fabrics also fluoresce under UV.

\section{RESULTS}

The description of the soft parts is primarily based on the main slab of the Scaphognathus crassirostris holotype, with the counterslab being 

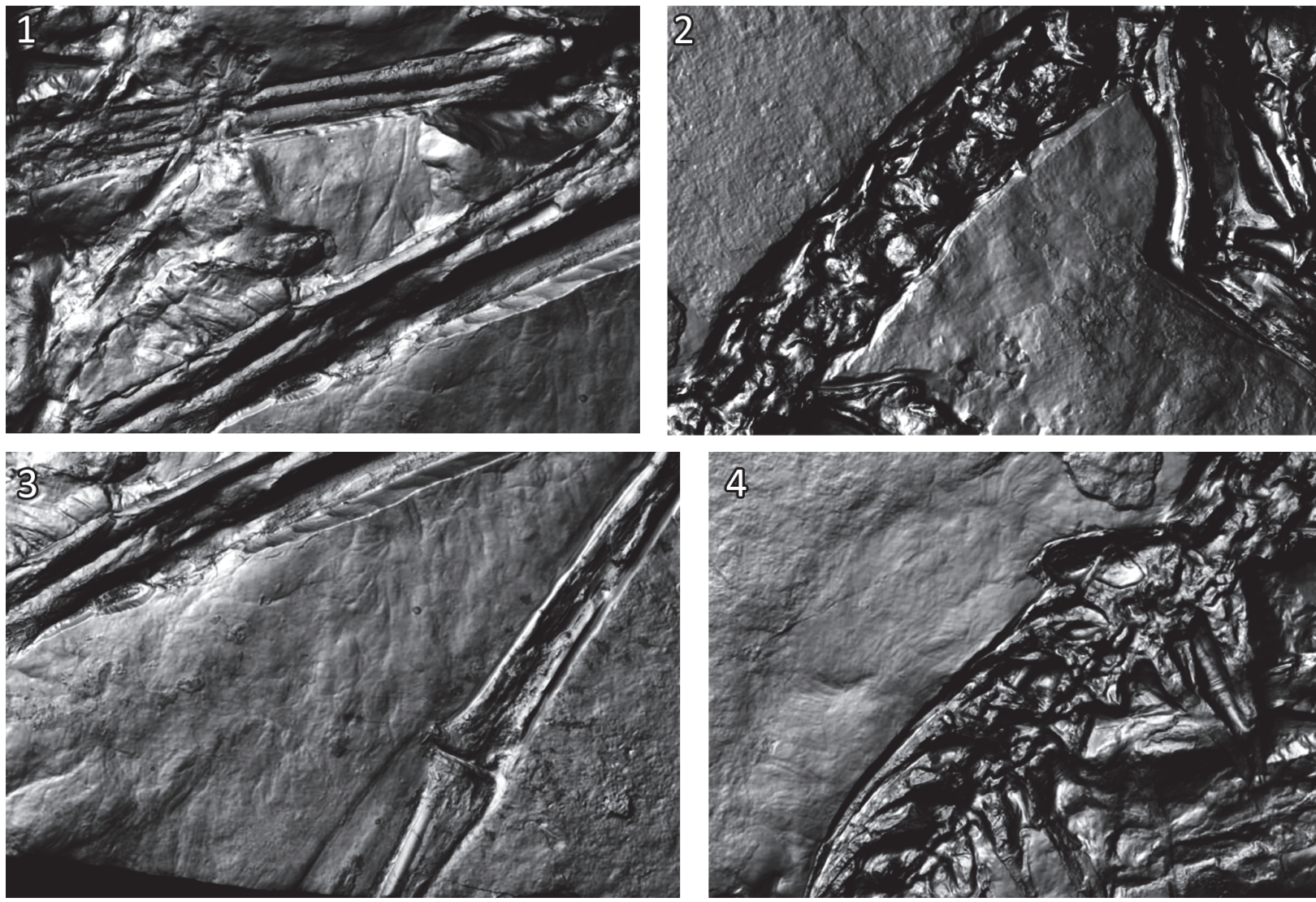

FIGURE 8. Magnification with RTIViewer enables zooming beyond the magnification of the photos by up to $200 \%$. While this digital magnification is based on interpolation, rendering modes without color, like the specular enhancement mode, provide relatively sharp images beyond magnifications of 100\% (Bogart, 2013b). 1, Blood vessels. 2, Pycnofibers ventral to the neck. 3, Aktinofibrils and displaced pycnofibers. 4, Dorsal pycnofibers.

less informative. Three types of soft tissue can be discerned: a) pycnofibers, b) aktinofibrils and c) blood vessel impressions on smooth wing membrane.

\section{Pycnofibers}

On the main slab, pycnofibers were reported by Goldfuß to the left (dorsal) of the dorsal vertebral column, ventral to the neck region, between the first and second phalanges of the right wing finger, and in the area between the right humerus and radius (Goldfuß, 1831; see translation in Supplementary Material 1). RTI also reveals pycnofibers in all of these areas (Figures 7 and 8). These pycnofibers are distinctive as individual fibers and as clusters of fibers. Ventral to the neck, the fibers are less clearly visible. In the UV images, pycnofibers are visible in these two regions as well and are possibly represented by the bright fluorescence ventral to the neck (Figure 9.1). In the UV images, those between the phalanges of the wing finger are distinctive as fibers, but less so in the dorsal area and not at all in the area ventral to the neck. The occurrence of the fibers between the phalanges of the wing finger does not necessary imply that they were originally present on the wing membrane, because we cannot exclude postmortal displacement. Accordingly, this patch may represent a part of the skin covering the trunk instead, as already noted by Tischlinger (2003).

On the counterslab, RTI also reveals the areas with pycnofibers between the first phalanges of the right wing finger and the area between the right humerus and radius (Figure 6.2).

\section{Aktinofibrils of the Actinopatagium}

One area of the specimen preserves part of the wing membrane, as indicated by a sharp border with the surrounding sediment, and as already observed by Goldfuß. Revealed by UV imaging, the actinofibrils concentrate at the distal joint of the first wing phalanx and fan out towards distal, parallel to the proximal part of the second wing phalanx, to the edge of the slab (Figure 9.4). The aktinofi- 

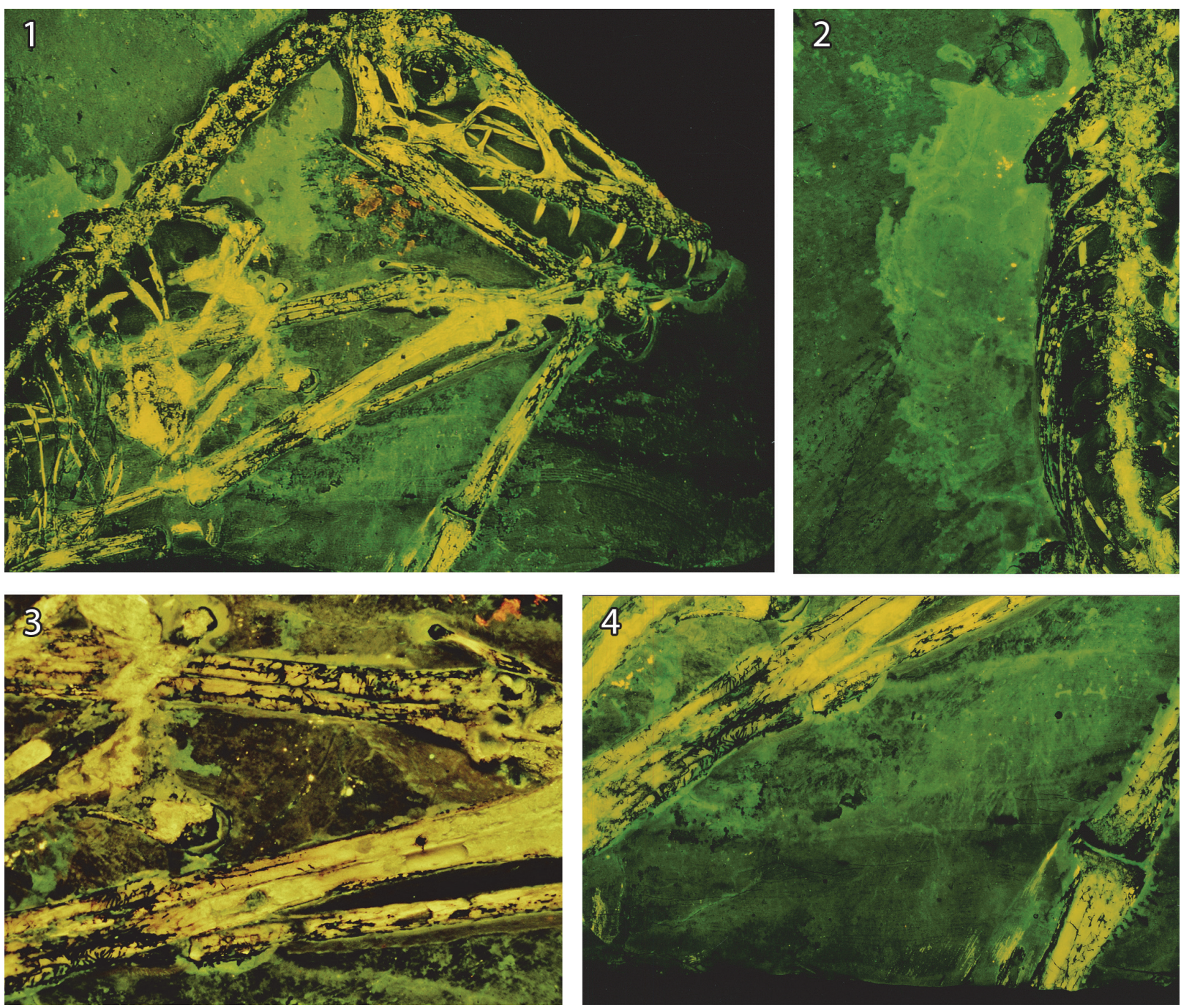

FIGURE 9. UV images of the main slab of Scaphognathus crassirostris SIPB Goldfuß 1304a modified from Tischlinger (2003). Bone apatite fluoresces yellow. 1, Main slab of holotype specimen. 2, Region of dorsal vertebral column on main slab. The light green hues suggest the presence of soft tissue. However, the impressions of the pycnofibers are not visible under UV light. 3, Wing membrane in the area enclosed by the left and right radius and ulna. Blood vessels are visible as dark lines. 4, Wing membrane aktinofibrils on the right wing finger next to the joint of the first and second phalanx. In the upper region of the wing membrane area, there are faintly visible displaced pycnofibers.

brils are also visible in the RTI images (Figures 7.3 and 8.3) on both slabs but less clearly so. Goldfuß interpreted the sharply demarcated region as "originating from a fold or a muscle" (Goldfuß, 1831; see translation in Supplementary Material 1).

\section{Blood Vessel Impressions on Smooth Wing Membrane}

The area enclosed by the left and right lower arm shows what most likely are the impressions of blood vessels in the wing membrane, as already noted by Goldfuß. In low-angle normal light, this area can be seen to have a particularly smooth surface on which there are rounded parallel grooves, some of which branch. The width of these grooves is $0.7-1.1 \mathrm{~mm}$. The structures are best discerned on the RTI (Figures 7.3, 8.1) but are only faintly and incompletely imaged by UV light (Figure 9.3). This region is best interpreted as the part of the wing membrane close to the body that lacks aktinofibrils, the tenopatagium. The blood vessel impressions are not identical to the second type of fibers described by Kellner et al. (2010), because they are more sinuous, branching, and thicker. On the counterslab, RTI also reveals the area of smooth wing membrane with blood vessels (Figure 6.2). The size of the blood vessels are similar to the main vessels on the "dark wing" specimen. 


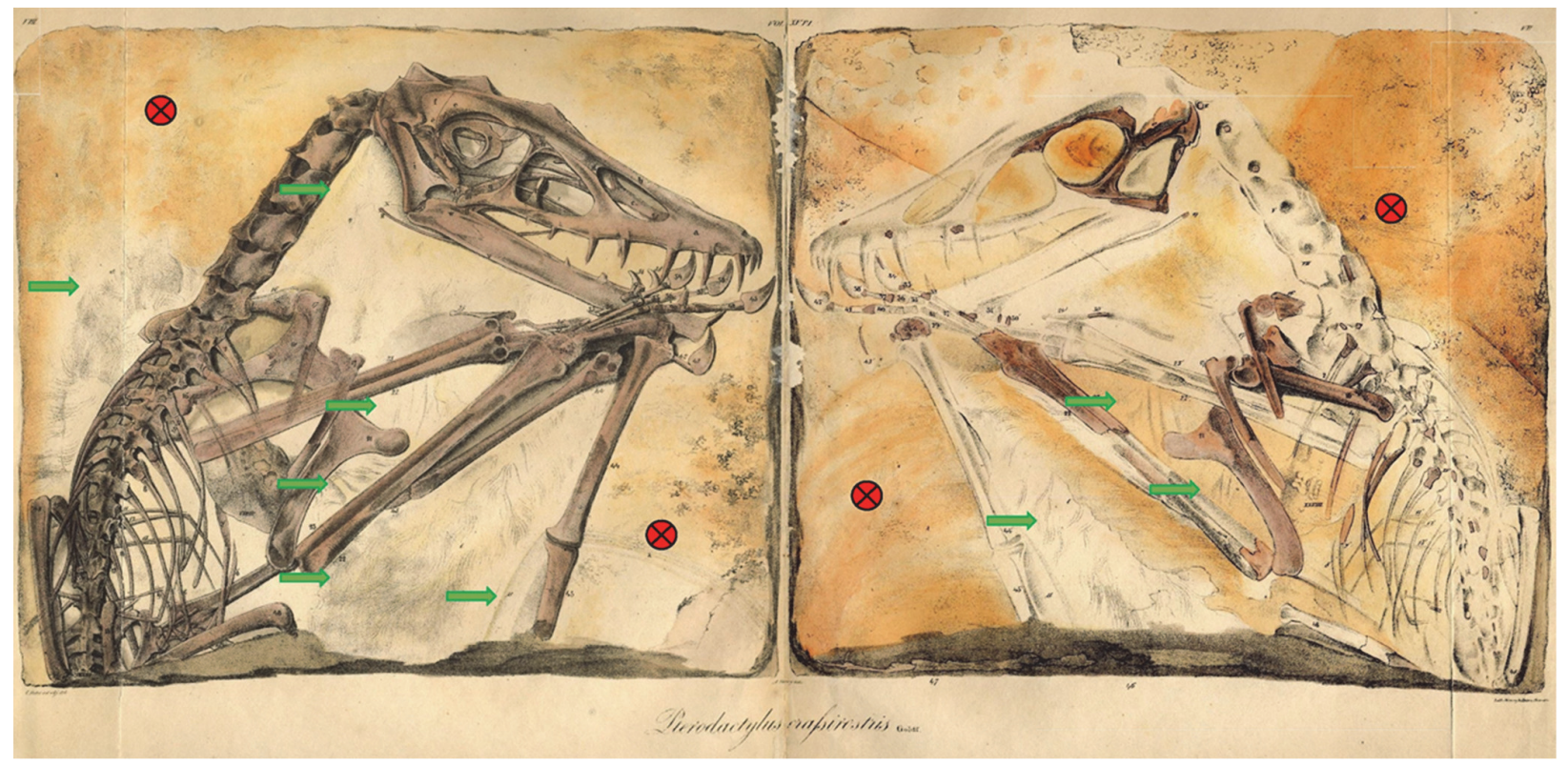

FIGURE 10. Comparison of soft tissue detection between this study and Goldfuß (1831, plates 7 and 8) on the main slab (left, SIPB Goldfuß 1304a) and counterslab (right, SIPB Goldfuß 1304b) of the holotype specimen of Scaphognathus crassirostris. Green arrows: Soft tissue depicted or described by Goldfuß and also detected by either RTI or UV light in this study. Red circles: No soft tissue detectable in this study.

However, it remains ambiguous if some these vessels branched in Scaphognathus crassirostris (Frey et al., 2003). Further are small vessels absent, which were observed on the "dark wing" specimen (Frey et al., 2003). This difference is most likely caused by the better preservation of that region in the "dark wing".

The area of smooth wing membrane between the blood vessel impressions also shows numerous small rounded pits (diameter $0.5-0.7 \mathrm{~mm}$ ) (Figures 7.3 and 8.1). Their origin remains unclear, and possible explanations are (1) gas bubbles, which developed underneath the skin (Dumser and Türkay, 2008), (2) gas bubbles in mud that was trapped between the wing membrane (Goldfuß, 1831), and (3) carbonate ooids (Reisdorf and Wuttke, 2012).

\section{Irreproducible Observations by Goldfuß}

Goldfuß also described soft tissue in some regions that we were unable to detect, neither by UV nor by RTI (Figure 10). These areas include the region dorsal of the neck and anterior to the right wing finger. The latter shows some Liesegang banding of iron oxides that seemingly were interpreted as pycnofibers by Goldfuß (and possibly the source of his description of "nearly inch-long hair"), but the former shows no distinctive structure or color changes.

\section{DISCUSSION}

\section{Soft Part Preservation in Scaphognathus crassirostris}

The two techniques employed here to reveal soft part preservation in the holotype of Scaphognathus crassirostris have different strengths and limitations and thus are complimentary, being best employed together. RTI enhances the microrelief and thus will work with impressions of soft parts, while UV imaging relies on substance preservation but will image areas without microrelief (Figures 79). Thus, the aktinofibrils of the wing membrane are poorly imaged by RTI but stand out clearly in UV light. The abundant pycnofibers, on the other hand, are better visible in the .rti files, with individual fibers discernible, whereas they only show up as a diffuse area of fluorescence in UV light. The blood vessel impressions on the smooth wing membrane are clearly visible in the rti files and with the naked eye but more vaguely as dark lines in the UV images (Figures 7.3, 8.1, 9.3).

We were thus able to reproduce all of Goldfuß' observations with the exception of the pycnofibers dorsal to the neck and anterior to the right wing finger (Figure 10). In addition, both of our methods detected aktinofibrils in the wing membrane, which Goldfuß had not observed (Figures 8.3 and 9.4). The Scaphognathus crassirostris 
holotype thus shows a subset (pycnofibers, tenopatagium with blood vessels, aktinopatagium) of soft part preservation that has more recently been described for other Solnhofen pterosaurs (see Frey et al., 2003, for a review) and for pterosaurs in general (Kellner et al., 2010; Witton, 2013). Only one layer of aktinofibrils seems to be preserved in the aktinopatagium, not several as in Jeholopterus (Kellner et al., 2010), but this may be because only a small and possibly marginal part of this region is preserved in the Scaphognathus crassirostris holotype.

\section{Strengths and Limitations of RTI in Paleontology}

One obvious contribution of RTI to paleontological research is the quick possibility to determine the best illumination of a specimen for scientific illustrations (Figure 5). However, there is more that RTI has to offer. Depending on the setup used, the technique requires a similar effort and mobility to photogrammetry, making it a useful method to gather data at different locations such as in paleontological collections. Probably the greatest advantage of RTI is its application for analyzing fine surface structures, by gaining additional information with the use of different rendering modes and the variability of incoming light. Hammer and Spocova (2013) compared the results of the specular enhancement mode with the whitening of fossils via ammonium chlorite.

In this study, the movement of the light source in combination with the specular enhancement mode made it possible to detect small differences in surface relief and therefore helped to analyze even fine details. Thus, the method is very useful for flat fossils, when small differences in surface relief may play an important role. Such flat fossils are typical for conservation deposits that preserve soft parts. The mobility and low costs is a notable advantage for the mobile highlight technique, which we view as superior to the dome technique for most paleontological studies.

Our results confirm archaeological studies that RTI has the potential to show elements that are not visible on conventional photographs and might be overlooked with the naked eye (Duffy et al., 2013). Since RTI only creates a two-dimensional image, we recommend photogrammetry for more three dimensional fossils. For flat fossils, RTI provides a quick addition to photogrammetry, especially when computing power is limited. Since the files do not contain native metric data, it is not possible to take measurements with "RTIViewer"
(Duffy et al., 2013). However, this problem is solved by placing a scale bar next to the object during the photo session. With the snapshot function of the viewer, it is possible to export images, and measurements can be subsequently made with a software like ImageJ.

Particularly for Solnhofen fossils, the results of RTI technique invite comparison with the UV light studies on soft tissue of pterosaurs (e.g., Frey et al., 2003). RTI is in some ways inferior, since it requires at least a slight difference in height for detecting soft tissue. The UV light technique, on the other hand, is less sensitive to relief preservation of mere impressions of soft tissues and produces regular photographic images that lack the illumination possibilities of RTI. In addition, UV fluorescence requires either soft tissues that are preserved as apatite, calcite or some other fluorescing mineral, or a contrast between fluorescing sediment and non-fluorescing areas such as blood vessels (Tischlinger and Frey, 2002, 2015). A case in point is the recently described specimen of Rhamphorhynchus (Hone et al., 2015) in which the soft parts seem to be purely preserved as impressions. UV imaging (Hone et al., 2015) failed to show any of the soft parts that the authors observed in normal light, and a study of this specimen by RTI may be informative. We recommend a combination of both methods to obtain an optimal result for future paleontological studies on soft tissue.

Further it is likely that even micropaleontological studies can profit from RTI, since archaeological studies already provided astonishing results for macrophotography using specific camera lenses and sub-millimeter spheres taken from fine ballpoint pens (Cosentino, 2013). Regarding the two different file formats .ptm and .rti, we observed less artifacts and better images with the .rti format. However, the static multi light setting, which is only available with .ptm files, yielded images with noteworthy illumination as well. Since image processing is quick, we recommend users to process photography into both file types.

\section{CONCLUSIONS}

One of the roots of paleobiology is found in the work of Georg August Goldfuß of the University of Bonn, in the description and illustration of a new pterosaur from the Solnhofen Limestone in 1831. However, both major contributions to paleobiology contained in his paper, the first published scientific reconstruction of an extinct life form and the recognition of soft part preservation and interpretation of these soft parts, were largely forgotten. Two tech- 
niques, reflectance transformation imaging and filtered UV light imaging, show that Goldfuß was correct in his interpretation of the preserved integumentary structures as pycnofibers and flight membrane. Therefore Goldfuß can be fully acknowledged as the first scientist to recognize the presence of pycnofibers in pterosaurs: "Thus, the Pterodactylus crassirostris was not covered by scales and shields like a reptile but by a fur of soft, nearly inch-long hairs, possibly in some places even by feathers. A similar cover can thus be assumed for its generic relatives." (Goldfuß, 1831; see translation in Supplementary Material 1). Further he envisioned pterosaurs as active flyers "As those (i.e., the bats), they were able to fly with their wings and probably hovered over the water's surface in order to catch insects, and possibly also water animals." (Goldfuß, 1831; see translation in Supplementary Material 1). In addition to the pycnofibers, we were able show the presence of aktinofibrils in this specimen. Therefore the observed soft tissue preservation of Scaphognathus crassirostris is in agreement with recent observations in other pterosaur specimens. Com- parison of the two imaging techniques indicates that RTI is good for low-relief, flat objects, even bringing out impression preservation. Filtered UV light imaging is useful for substance preservation, because fluorescing minerals will provide information on soft parts that show only weak or no surface structure. Further, we would like to encourage the use of RTI in paleontological studies. In addition to the images created with the snapshot function (Figures 6-8), we have added the RTI files of this study to the Supplementary Materials (Supplementary Material 2 and 3 ), so that the different settings can be interactively explored by the reader.

\section{ACKNOWLEDGMENTS}

We thank M. Coates (Chicago) for introducing one of us (KRKJ) to RTI/PTM imaging. We also thank the RTI development team for helpful advice. Finally, we thank the reviewers for their efforts, which greatly improved this paper. This is contribution number 5 of DFG Research Unit 2685 "Fossiliation".

\section{REFERENCES}

Barbosa, J.G, Proença, A.J., and Sobral, J.L. 2007a. RTIBuilder. Version 2.0.2. Universidade do Minho, Braga. http://culturalheritageimaging.org/What_We_Offer/Downloads/Process/ index.html

Barbosa, J.G., Sobral, J.L., and Proença, A.J. 2007b. Imaging techniques to simplify the PTM generation of a bas-relief, p. 28-31. In loannides, M., Arnold, D.B., Niccolucci, F., and Mania. K. (eds.), The 7th International Symposium on Virtual Reality, Archaeology and Intelligent Cultural Heritage (VAST 2006). Eurographics Association, Nicosia.

Becker, T. 1999. Georg August Goldfuß und die Begründung der Naturwissenschaften in Bonn, p. 182-189. In Borchard, K. (ed.), Chronik des Akademischen Jahres:1997/1998. Universität Bonn, Bonn.

Bennett, S.C. 2000. Pterosaur flight: The role of actinofibrils in wing function. Historical Biology, 14:255-284. https://doi.org/10.1080/10292380009380572

Bogart, J. 2013a. Reflectance Transformation Imaging: Guide to Highlight Image Capture. Cultural Heritage Imaging, San Francisco. http://culturalheritageimaging.org/ What_We_Offer/Downloads/RTI_HIt_Capture_Guide_v2_0.pdf

Bogart, J. 2013b. Reflectance Transformation Imaging: Guide to RTIViewer. Cultural Heritage Imaging, San Francisco. http://culturalheritageimaging.org/What_We_Offer/Downloads/ rtiviewer/RTIViewer_Guide_v1_1.pdf

Broili, F. 1927. Ein Rhamphorhynchus mit Spuren von Haarbedeckung. Sitzungsberichte der Bayrischen Akademie der Wissenschaften, Mathematisch-Naturwissenschaftliche Abteilung, 1927:49-67.

Broili, F. 1938. Beobachtungen an Pterodactylus. Sitzungsberichte der Bayrischen Akademie der Wissenschaften, Mathematisch-Naturwissenschaftliche Abteilung, 1938:139-154.

Buckland, W. 1836. Geology and Mineralogy Considered with Reference to Natural Theology. William Pickering, London. 
Corsini, M., Palma, G., Barbosa, J.G., Bourret, R., and Isaksen, L. 2012. RTIViewer. Version 1.1. Visual Computing Laboratory, Pisa. http://culturalheritageimaging.org/What_We_Offer/ Downloads/View/index.html

Cosentino, A. 2013. Macro photography for reflectance transformation imaging. E-conservation Journal, 1:71-85. https://doi.org/10.18236/econs1.201310

Cremer, S.G. 2001. Nicolaus Christian Hohe (1798-1868). Universitätszeichenlehrer in Bonn. Bonner Studien zur Kunstgeschichte 16. Lit Verlag, Münster.

Dalla Vecchia, F.M. 1994. A new pterosaur (Reptilia, Pterosauria) from the Norian (Late Triassic) of Friuli (North eastern Italy). Preliminary note. Gortania, 16:59-66.

Dellepiane, M., Corsini, M., Callieri, M., and Scopigno, R. 2006. High quality PTM acquisition: Reflection transformation imaging for large objects, p. 179-186. In loannides, M., Arnold, D.B., Niccolucci, F., and Mania, K. (eds.), The 7th International Symposium on Virtual Reality, Archaeology and Intelligent Cultural Heritage (VAST 2006). Eurographics Association, Nicosia.

Döderlein, L. 1929. Rhamphorhynchus und sein Schwanzsegel. Sitzungsberichte der Bayrischen Akademie der Wissenschaften, Mathematisch-Naturwissenschaftliche Abteilung, 1929:65-76.

Duffy, S.M., Bryan, P., Earl, G., Beale, G., Pagi, H., and Kotoula, E. 2013. Multi-light Imaging Techniques for Heritage Application: PTM Guidelines. English Heritage, Swindon.

Dumser, T.K. and Türkay, M. 2008. Postmortem changes of human bodies on the bathyal sea floor-Two cases of aircraft accidents above the open sea. Journal of Forensic Sciences, 53:1049-1052. https://doi.org/10.1111/j.1556-4029.2008.00816.x

Earl, G., Basford, P., Bischoff, A., Bowman, A., Crowther, C., Dahl, J., Hodgson, M., Isaksen, L., Kotoula, E., Martinez, K., Pagi, H., and Piquette, K.E. 2011. Reflectance transformation imaging systems for ancient documentary artefacts, p. 147-154. In Dunn, S., Bowen, J.P., and $\mathrm{Ng}, \mathrm{K}$. (eds.), Proceedings of the 2011 International Conference on Electronic Visualisation and the Arts (EVA 2011). British Computer Society (BCS), Swindon.

Earl, G., Martinez, K., and Malzbender, T. 2010. Archaeological applications of polynomial texture mapping: Analysis, conservation and representation. Journal of Archaeological Science, 37:2040-2050. https://doi.org/10.1016/j.jas.2010.03.009

Frey, E. and Tischlinger, H. 2000. Weichteilanatomie der Flugsaurierfüße und Bau der Scheitelkämme: Neue Pterosaurierfunde aus den Solnhofener Schichten (Bayern) und der Crato-Formation (Brasilien). Archaeopteryx, 18:1-16.

Frey, E. and Tischlinger, H. 2012. The Late Jurassic pterosaur Rhamphorhynchus, a frequent victim of the ganoid fish Aspidorhynchus? PLoS ONE, 7:e31945. https://doi.org/10.1371/ journal.pone.0031945

Frey, E., Tischlinger, H., Buchy, M.-C., and Martill, D.M. 2003. New specimens of Pterosauria (Reptilia) with soft parts with implications for pterosaurian anatomy and locomotion. Geological Society, London, Special Publications, 217:233-266. https://doi.org/10.1144/ GSL.SP.2003.217.01.14

Goldfuß, A. 1831. Beiträge zur Kenntnis verschiedener Reptilien der Vorwelt. Nova Acta Physico-Medica Academiae Caesareae Leopoldino-Carolinae Naturae Curiosorum, 15:61128.

Hammer, Ø., Bengtson, S., Malzbender, T., and Gelb, D. 2002. Imaging fossils using reflectance transformation and interactive manipulation of virtual light sources. Palaeontologia Electronica, 4:1-9. palaeo-electronica.org/2002_1/fossils/issue1_02.htm

Hammer, $\varnothing$. and Spocova, J. 2013. Virtual whitening of fossils using polynomial texture mapping. Palaeontologia Electronica, 16:1-10. https://doi.org/10.26879/384 palaeo-electronica.org/content/2013/465-virtual-whitening-of-fossils

Hone, D., Henderson, D.M., Therrien, F., and Habib, M.B. 2015. A specimen of Rhamphorhynchus with soft tissue preservation, stomach contents and a putative coprolite. PeerJ, 3:e1191. https://doi.org/10.7717/peerj.1191

Kellner, A.W.A. 1996. Reinterpretation of a remarkably well preserved pterosaur soft tissue from the Early Cretaceous of Brazil. Journal of Vertebrate Paleontology, 16:718-722. https:// doi.org/10.1080/02724634.1996.10011360

Kellner, A.W.A., Wang, X., Tischlinger, H., de Almeida Campos, D., Hone, D.W.E., and Meng, X. 2010. The soft tissue of Jeholopterus (Pterosauria, Anurognathidae, Batrachognathinae) and the structure of the pterosaur wing membrane. Proceedings of the Royal Society B: Biological Sciences, 277:321-329. https://doi.org/10.1098/rspb.2009.0846 
Kotoula, E. 2012. Application of rti in museum conservation, p. 232-240. In Earl, G. (ed.), Archaeology in the Digital Era. Papers from the 40th Annual Conference of Computer Applications and Quantitative Methods in Archaeology (CAA). Amsterdam University Press, Amsterdam.

Langer, W. 1969. Georg August Goldfuß. Eine biographische Skizze. Bonner Geschichtsblätter, 23:229-243.

Langer, W. 1990. Frühe Bilder aus der Vorzeit. Fossilien, 5:202-205.

Langer, W. 2003. Die ehemalige Rosenburg in Bonn-Kessenich. Rheinische Heimatpflege, 40:141-145.

Malzbender, T., Gelb, D., and Wolters, H. 2001. Polynomial texture maps, 519-528. In Pocock, L. (ed.), Proceedings of ACM SIGGRAPH. ACM, New York. https://doi.org/10.1145/ 383259.383320

Malzbender, T., Gelb, D., Wolters, H., and Zuckermann, B. 2000. Enhancement of Shape Perception by Surface Reflectance Transformation. Hewlett-Packard Technical Report, HPL2000-38, March 2000. Hewlett-Packard Company, Palo Alto. https:// pdfs.semanticscholar.org/9aca/539da7110ef7084c74b328e174d964b5c526.pdf

Marsh, O.C. 1882. The wings of pterodactyls. American Journal of Science, 23:251-256. https:// doi.org/10.2475/ajs.s3-23.136.251

Martill, D. 2014. Dimorphodon and the Reverend George Howman's noctivagous flying dragon: The earliest restoration of a pterosaur in its natural habitat. Proceedings of the Geologists' Association, 125:120-130. https://doi.org/10.1016/j.pgeola.2013.03.003

Meyer, v.H. 1846. Pterodactylus (Rhamphorhynchus) Gemmingi aus dem Kalkschiefer von Solenhofen. Palaeontographica, 1:1-20.

Meyer, v.H. 1860. Zur Fauna der Vorwelt, Vierte Abt.: Reptilien aus dem lithographischen Schiefer des Jura in Deutschland und Frankreich. Heinrich Keller Verlag, Frankfurt am Main.

Newman, E. 1843. Note on the Pterodactyl tribe considered as marsupial bats. The Zoologist, 1:129-131.

Padian, K. and Rayner, L. 1993. The wings of pterosaurs. American Journal of Science, 293(A):91-166. https://doi.org/10.2475/ajs.293.a.91

Palma, G., Corsini, M., Cignoni, P., Scopigno, R., and Mudge, M. 2010. Dynamic shading enhancement for reflectance transformation imaging. Journal on Computing and Cultural Heritage, 3:1-20. https://doi.org/10.1145/1841317.1841321

Piquette, K.E. 2011. Reflectance transformation imaging (RTI) and ancient Egyptian material culture. Damqatum: The CEHAO Newsletter, 7:16-20.

Reisdorf, A.G. and Wuttke, M. 2012. Re-evaluating moodie's opisthotonic-posture hypothesis in fossil vertebrates Part I: Reptiles—the taphonomy of the bipedal dinosaurs Compsognathus longipes and Juravenator starki from the Solnhofen Archipelago (Jurassic, Germany). Palaeobiodiversity and Palaeoenvironments, 92:119-168. https://doi.org/10.1007/s12549011-0068-y

Rudwick, M.J.S. 1992. Scenes from Deep Time. Early Pictorial Representations of the Prehistoric World. University of Chicago Press, Chicago.

Schaller, D. 1985. Wing evolution, p. 333-348. In Hecht, M.K., Ostrom, J.H., Viohl, G., and Wellnhofer, P. (eds.), Proceedings of the International Archaeopteryx Conference, Eichstätt 1984. Freunde des Jura-Museums Eichstätt, Eichstätt.

Sharov, H.G. 1971. New flying reptiles from the Mesozoic of Kazakhstan and Kirgizia. Trudy Academia Nauk, Palaeontoloitscheki Instiut, 130:104-113.

Thomann, B. 2016. Georg August Goldfuß Zoologe und Geologe (1782-1848). Internetportal Rheinische Geschichte. http://www.rheinische-geschichte.Ivr.de/Persoenlichkeiten/georgaugust-goldfuss/DE-2086/lido/57c6c96de3a9d2.85745885 (Accessed 29.07.2016)

Tischlinger, H. 2002. Der Eichstätter Archaeopteryx im langwelligen UV-Licht. Archaeopteryx, 20:21-38.

Tischlinger, H. 2003. Professor Goldfuß und sein "Dickschnabel" aus dem Altmühljura. Globulus Beiträge der Natur- und kulturwissenschaftlichen Gesellschaft, 10:95-104.

Tischlinger, H. 2005. Neue Informationen zum Berliner Exemplar von Archaeopteryx lithographica H. v. Meyer 1861. Archaeopteryx, 23:33-50.

Tischlinger, H. 2006. ... und Goldfuß hatte doch Recht! Fossilien, 23:245-253.

Tischlinger, H. 2015. Arbeiten mit ultraviolettem Licht, p. 109-113. In Arratia, G., Schultze, H.P., Tischlinger, H., and Viohl, G. (eds.), Solnhofen, ein Fenster in die Jurazeit. Dr. Friedrich Pfeil, München. 
Tischlinger, H. and Arratia, G. 2013. Ultraviolet light as a tool for investigating Mesozoic fishes, with a focus on the ichthyofauna of the Solnhofen archipelago, p. 549-560. In Arratia, G., Schultze, H.P., and Wilson, M.V.H. (eds.), Mesozoic Fishes 5 - Global Diversity and Evolution. Dr. Friedrich Pfeil, München.

Tischlinger, H. and Frey, E. 2002. Ein Rhamphorhynchus (Pterosauria, Reptilia) mit ungewöhnlicher Flughauterhaltung aus dem Solnhofener Plattenkalk. Archaeopteryx, 20:120.

Tischlinger, H. and Frey, E. 2015. Flugsaurier (Pterosauria), p. 459-480. In Arratia, G., Schultze, H.-P., Tischlinger, H., and Viohl, G. (eds.), Solnhofen - Ein Fenster in die Jurazeit. Dr. Friedrich Pfeil, München.

Unwin, D.M. and Bakhurina, N.N. 1994. Sordes pilosus and the nature of the pterosaur flight apparatus. Nature, 371:62-64. https://doi.org/10.1038/371062a0

Wanderer, K. 1908. Rhamphorhynchus gemmingi H. v. Meyer, ein Exemplar mit teilweise erhaltener Flughaut aus dem Kgl. Mineralog. Geol. Museum zu Dresden. Palaeontographica, 55:195-216.

Wang, X., Zhou, Z., Zhang, F., and Xu, X. 2002. A nearly completely articulated rhamphorhynchoid pterosaur with exceptionally well-preserved wing membranes and "hairs" from Inner Mongolia, northeast China. Chinese Science Bulletin, 47:226-230.

Wellnhofer, P. 1970. Die Pterodactyloidea (Pterosauria) der Oberjura-Plattenkalke Süddeutschlands. Abhandlungen der Bayerischen Akademie der Wissenschaften, Mathematisch-Naturwissenschaftliche Klasse, Neue Folge, 141:1-113.

Wellnhofer, P. 1975. Die Rhamphorhynchoidea (Pterosauria) der Oberjura-Plattenkalke Süddeutschlands. III Palökologie und Stammesgeschichte. Palaeontographica, 149:1-30.

Wellnhofer, P. 1991. The Illustrated Encyclopedia of Pterosaurs. Crescent Books, New York.

Wiman, C. 1925. Über Pterodactylus westmani und andere Flugsaurier. Bulletin of the Geological Institute of the University of Upsala, 20:1-38.

Winkler, T.C. 1874. Le Pterodactylus du Musée Teyler. Archives du Musée Teyler, 3:1-11.

Witton, M.P. 2013. Pterosaurs. Natural History, Evolution, Anatomy. Princeton University Press, Princeton. https://doi.org/10.1515/9781400847655

Zittel, K. Av. 1882. Über Flugsaurier aus dem lithographischen Schiefer Bayerns. Palaeontographica, 29:47-80. 


\section{SUPPLEMENTARY MATERIALS}

The Supplementary Materials are combined in a zipped file available online https://palaeo-electronica.org/content/2018/2308-scaphognathus-in-rti-and-uv

1. Translation of selected parts of Goldfuß (1831) by PMS.

2. RTI file of the main slab of Scaphognathus crassirostris (holotype). Viewable with RTIViewer (Corsini et al., 2002).

3. RTI file of the counter slab of Scaphognathus (holotype). Viewable with RTIViewer (Corsini et al., 2002). 